\title{
FRAUDES INOCENTES E O SABER CONVENCIONAL A ECONOMIA DO NOSSO TEMPO
}

\section{Resenha do livro A economia das fraudes inocentes: verdades para o nosso tempo, de John Kenneth Galbraith}

\author{
São Paulo: Companhia das Letras, 2004, 84 p.
}

\section{Eneuton Pessoa de Carvalho*}

John kenneth Galbraith dispensa apresentações. Aos 96 anos, 70 dos quais voltados à economia, Galbraith brinda o leitor com interessante opúsculo a respeito da discrepância que há entre a realidade econômica e o que denomina de "a sabedoria convencional".

O livro é provocativo do início ao fim. Começa perguntando como é possível a fraude inocente, ou como a inocência pode ser fraudulenta? Se há inocência, ela está a indicar ausência do sentimento de culpa ou responsabilidade. Se há fraude, ela remete à deturpação, mais ou menos deliberada, da realidade. A ocorrência simultânea de ambas é decorrência, em parte do senso comum sobre a atividade econômica, e em parte da teoria econômica tradicional e do seu ensino, voltados para modismos e a justificação de interesses. Esta é a idéia-síntese que permeia a obra "Economia das Fraudes Inocentes".

No decorrer dos capítulos o Autor identifica fraudes sob a forma de "crenças para benefício próprio e contra-sensos deliberados". Um exemplo de contra-senso deliberado é a substituição na designação de sistema econômico: de capitalismo para "sistema de mercado". A conotação de poder e dominação que o termo capitalismo evoca, vê-se omitida pelo termo "sistema de mercado", amplamente aceito porque encobre o significado historicamente negativo do termo capitalismo. Dentre as crenças fraudulentas mencionadas por Galbraith, destaca-se a da "soberania do consumidor", em descompasso com a realidade da grande empresa, com seu poder de mercado e de controle sobre o consumidor, por meio da propaganda e o marketing. Seguem-se a falsa idéia

*Professor da UERGS-Universidade Estadual do Rio Grande do Sul, e-mail: eneuton@uol.com.br 
da existência de um único mundo do trabalho; a propalada dicotomia entre os setores público e privado: o reino da política versus o da economia; a idéia de que a burocracia com seus interesses auto referidos e sua tendência à expansão se restringe aos negócios de Estado, desconsiderando que sua presença no mundo das corporações é tão real quanto na esfera pública, etc.

Mas há ainda aquelas fraudes que Galbraith identifica como "não tão inocentes", porquanto associadas à manipulação deliberada de informações, visando interesses pecuniários. Os recentes escândalos empresariais americanos - vide o caso Enrom - seriam exemplo desse tipo de fraude. $\mathrm{O}$ aspecto chave dessas fraudes é o controle ilimitado dos executivos sobre a grande empresa: as assembléias de acionistas e os conselhos administrativos tornaram-se na prática instâncias decorativas, sem influência maior sobre o cotidiano da empresa moderna. A influência dos executivos chega aos órgãos de regulação e controle, como ficou evidenciado na atuação de auditorias tendenciosas e de funcionários públicos corruptos, ambos participantes daqueles escândalos.

A sociedade não dispõe de mecanismos mais eficientes para a prevenção de tais crimes, dentre outras coisas porque persiste o mito do acionista controlador da empresa, e de que o capitalismo funciona de forma rotineira, concorrencial. Não se leva em conta o poder da grande empresa, e o poder discricionário de seus executivos de concederem benefícios e vantagens a si próprios, às vezes, indevidamente. Isto, num mundo que tem no enriquecimento pessoal o indicador básico do mérito profissional. Os marcos regulatórios são, assim, insuficientes para coibir tais crimes. E isto é grave, haja vista o papel fundamental da grande empresa para o bem ou mal-estar econômico-social no mundo hodierno.

Outro tipo de fraude "não tão inocente" ocorre no mundo das finanças. Neste mundo, geralmente os encarregados de fazer previsões são muito apreciados e, por isso, bem remunerados. Acontece que o futuro, enquanto resultado da combinação de uma soma de eventos, sobre os quais não se tem controle, é desconhecido. O desempenho futuro dos negócios é, assim, algo imprevisível. No entanto, tais profissionais atuam como se tivessem o poder de desvendar o futuro. O uso de recursos matemáticos e estatísticos, o sucesso fortuito, além da autoconfiança, estimulam a crença nessas previsões. Porém, tais previsões não deixam de ser interessadas. Da 
parte dos analistas e homens de negócios, prevê-se aquilo que se quer ouvir, lucrar ou obter retorno. Nesses casos, esperança e necessidade encobrem a realidade.

Galbraith chega, enfim, ao que considera "a mais prestigiosa forma de fraude". A irrelevância do FED e de seus instrumentos para influenciar o desempenho da economia americana, a despeito de sua grande respeitabilidade. Suas medidas são manifestamente inócuas, muito embora sejam as mais aprovadas e aceitas. Essa aura de respeitabilidade tem base sólida: ela decorre do poder e prestígio que detêm aqueles que lidam com dinheiro.

Com traço leve, mesclando humor e fina ironia, marca registrada de seus escritos, a "Economia das Fraudes Inocentes - verdades para o nosso tempo" é um refinamento das principais idéias de Galbraith desenvolvidas ao longo de sua vida de homem de pensamento e de Estado. Num ponto, no entanto, Galbraith manifesta mudança de posição.

Na sua Obra de 1994, "Uma viagem pelo tempo econômico", Galbraith considera o capitalismo e a economia avançada moderna, no Ocidente e nos Estados Unidos em particular, como um sistema essencialmente pacífico, excetuando-se possíveis tensões advindas de uma depressão prolongada. Dez anos depois, os acontecimentos na arena internacional e as mudanças na política externa americana o fizeram mudar de posição. Em 2004, Galbraith identifica nos interesses econômicos do establishment militar, o complexo industrial-militar, o sustentáculo dos gastos do Estado americano com armamento, da política agressiva praticada pelo atual governo do país, e em última instância, da guerra e suas conseqüências. Coisa obscurecida pelo mito da existência de dois setores distintos: o público e o privado.

Como observador privilegiado e atento do século XX, suas perspectivas para o Século que se inicia não são, assim, animadoras. A dominância dos interesses econômicos sobre a política externa americana apontam para a continuação da guerra e de seus efeitos, dentre os quais, a suspensão dos valores da civilização humana: o nosso supremo fracasso. 